\title{
Effect of straw retention on carbon footprint under different cropping sequences in Northeast China
}

\author{
Qiulai Song ${ }^{1,2} \cdot$ Jie Zhu ${ }^{3} \cdot$ Zhenping Gong $^{4} \cdot$ Yanjiang Feng ${ }^{1} \cdot$ Qi Wang ${ }^{1} \cdot$ Yu Sun ${ }^{1} \cdot$ Xiannan Zeng $^{1} \cdot$ Yongcai Lai $^{1}$
}

Received: 23 February 2021 / Accepted: 3 May 2021 / Published online: 20 May 2021

(C) The Author(s) 2021

\begin{abstract}
Inappropriate farm management practices can lead to increased agricultural inputs and changes in atmospheric greenhouse gas (GHG) emissions, impacting climate change. This study was initiated in 2012 to assess the potential for straw retention to mitigate the negative environmental impact of various cropping systems on the Songnen Plain using the life cycle assessment (LCA) method combined with field survey data. Straw retention (STR) and straw removal (STM) treatments were established in continuous corn (CC) and corn-soybean rotation (CS) systems in a split-plot experiment. The effects of straw retention on the carbon footprint (CF) of cropland under different cropping systems were compared. The CF under CC was $2434-2707 \mathrm{~kg} \mathrm{CO}_{2}$ $\mathrm{ha}^{-1}$ year $^{-1}, 49-57 \%$ higher than that under CS. Nitrogen fertilizer produced the most $\mathrm{CO}_{2}$, accounting for $66-80 \%$ of the CF. The carbon balances of the CC and CS systems with STR were positive, with annual carbon sequestrations of 9633 and $2716 \mathrm{~kg}$ $\mathrm{CO}_{2}$ ha $^{-1}$ year $^{-1}$, respectively. The carbon balance (CB) of CC-STR was $255 \%$ higher than that of CS-STR. This study demonstrates that STR under CC cultivation is an environmentally friendly practice for agricultural production, can help achieve high-yield and low-carbon production in rainfed cropland, and can support the sustainable development of grain production in Northeast China.
\end{abstract}

Keywords Straw retention $\cdot$ Continuous corn $\cdot$ Corn-soybean rotation $\cdot$ Carbon footprint $\cdot$ Forming factors $\cdot$ Carbon balance

\section{Introduction}

Greenhouse gas (GHG) emissions are the most critical factors influencing global climate change, and climate change poses a serious threat to the natural environment and human economic development (IPCC 2013). Agricultural ecosystem is the primary source of GHGs released by human activity (Bennetzen et al. 2016; Linquist et al. 2012). Various cropland

Responsible Editor: Philippe Garrigues

Zhenping Gong

gzpyx2004@163.com

1 Institute of Crop Cultivation and Tillage, Heilongjiang Academy of Agricultural Sciences, Harbin 150086, Heilongjiang, China

2 Key Laboratory for Combining Farming and Animal Husbandry, Ministry of Agriculture and Rural Affairs, Harbin 150086, Heilongjiang, China

3 Beijing Chalk Blue Sky Technology Co., Ltd, Beijing 100102, China

4 College of Agriculture, Northeast Agricultural University, Harbin 150030, China management practices affect the mineralization of soil organic matter and alter carbon emissions. Moreover, differences inputs of chemical fertilizers, human activities, and fuels create variation in carbon emissions from agricultural inputs under different management practices, indirectly influencing the energy consumption and carbon cycling of systems ( $\mathrm{Li}$ et al. 2002; Lal 2004; Larsen and Hertwich 2011; Wang et al. 2015a; Zhang et al. 2015; Meier et al. 2020). The carbon footprint (CF), the impact of carbon emissions on the global environment, is an assessment of direct or indirect $\mathrm{CO}_{2}$ emissions caused by particular activities or estimated cumulatively during the life cycles of particular products (Peters 2010; Duan et al. 2011; Adewale et al. 2019). The factors influencing $\mathrm{CFs}$ include the $\mathrm{CO}_{2}$ emissions from farmland soil and crops and indirect $\mathrm{CO}_{2}$ emissions from the production, storage, and transportation of agricultural production materials (Liu et al. 2016; Lal et al. 2019).

CFs are affected by many factors, such as regional conditions, agricultural production systems, and crop types (Günther et al. 2017; Houshyar and Grundmann 2017; Yadav et al. 2017; Liu et al. 2018; Xue et al. 2018). To quantify the CFs of different agricultural production systems 
around the world, many studies of regional agricultural CFs, crop CFs, and food CFs have been conducted (Hillier et al. 2009a; Nelson et al. 2009; Wang et al. 2015b). Previous studies have quantified the CFs of different crops and patterns of variation in different regions (Hillier et al. 2009b; Röös et al. 2010; Clay et al. 2012; Gan et al. 2014; Wang et al. 2015a, 2016; Günther et al. 2017; Houshyar and Grundmann 2017; Pishgar-Komleh et al. 2017; Yadav et al. 2017; Heusala et al. 2020), providing a basis for reducing carbon emissions in agricultural production processes. The $\mathrm{CF}$ of crop production can be reduced by changing management methods and implementing low-carbon technologies, such as conservation tillage, optimized irrigation, and fertilizer application (Zhang et al. 2016; Yadav et al. 2018). Wang et al. (2020) assessed the CFs of four different cropping systems, and the results indicated that cotton monoculture was the best (i.e., had the lowest $\mathrm{CF}$ ) of these cropping systems in low-fertility plots and that winter wheat intercropped with cotton was best (i.e., had the lowest $\mathrm{CF}$ ) in high-fertility plots.

Straw retention (STR) also has an important influence on the CF. Lal et al. (2019) demonstrated that STR increased CFs by approximately $10 \%$. Li et al. (2020) further pointed out that the CF is strongly affected by the amount of straw used, and when compared with no STR treatment, the CF did not increase until field application of one-third of the STR and then increased as straw application was further increased. Bai et al. (2021), under the same natural conditions in semiarid areas of Northwest China, showed that STR increased GHG emissions, but the CF decreased by $45-55 \%$ due to the strong acceleration of soil organic carbon (SOC) accumulation. Therefore, the effects of STR on the CF observed by different researchers in different regions are inconsistent. These studies have systematically elucidated the impacts of crop rotation on CFs as well as the responses of soil carbon emissions and CF to farming practices, including STR. However, little has been reported on how the combined effects of crop rotation and STR affect the CF.

The Songnen Plain is a major grain-producing area in Northeast China. This plain region is located in Heilongjiang and Jilin Provinces. Rainfed cropland in this region is mainly planted with corn and soybean. The cropping system involves one harvest per year, and the major cropping patterns are continuous corn (CC) and corn-soybean rotation (CS). In recent years, the Chinese government has completely prohibited burning crop straw in the field and has vigorously promoted straw return technology. The area of crop straw return has increased year-by-year in the Songnen Plain. However, there has been no systematic study of the effects of STR on the CF under these two cropping patterns (CC and CS) on the Songnen Plain. We hypothesized that CFs are jointly influenced by differences in cropping pattern (CC or CS) and straw-use pattern, e.g., STR or straw removal (STM). Our objective was to use life cycle assessment (LCA) to evaluate the impact of STR on CFs under two cropping patterns (CC and CS) on the Songnen Plain through direct measurement of soil carbon emissions and indirect emission inventories.

\section{Materials and methods}

\section{Experimental site}

The field experiment was conducted at the Xiangfang Experimental Practice Base of Northeast Agricultural University. During the experimental period, the total annual rainfall was $485 \mathrm{~mm}$ (2013) and $454 \mathrm{~mm}$ (2014). This study began in 2012, and data were collected from 2013 to 2014 . The cropping patterns at the experimental site were mainly CC and CS. The cropping sequence of CC was corn in both 2013 and 2014, and the cropping sequence of CS was corn in 2013 followed by soybean in 2014. The basic soil physicochemical properties $(0-20 \mathrm{~cm}$ depth) are listed in Table 1 .

\section{Experimental design}

A two-factor split-plot design was used in this study. The main plot factor was cropping pattern (CC vs. CS), and the subplot factor was straw management (STR vs. STM). There were four treatments: continuous corn cropping with straw retention (CC-STR), continuous corn cropping with straw removal (CC-STM), corn-soybean rotation with straw retention (CSSTR), and corn-soybean rotation with straw removal (CSSTM). Each treatment had three replicates for a total of 12 plots, with $780 \mathrm{~m}^{2}$ per plot.

In the STR treatment, the corn straw was cut into pieces $(\leq 10 \mathrm{~cm})$ after harvest in autumn and returned to the field. A ridge subsoiling stubble machine was used to deep-loosen the soil to $25 \mathrm{~cm}$ and form a seeding strip of $32 \mathrm{~cm}$. In the STM treatment, the straw was removed from the field after harvest, the stubble and soil were plowed to a depth of $25 \mathrm{~cm}$, and a rotary cultivation machine was used to crush the soil and ridge at the same time.

In all four treatments, the ridge spacing was $70 \mathrm{~cm}$. During the crop seedling stage, the soil was cultivated with medium tillage.

During the 2-year experimental period, the same crop cultivar, fertilization, and weeding schemes were used, and the corn and soybean were sown and harvested at the same time. The Dongnong 253 corn (Zea mays L.) cultivar was sown mechanically on May 2 and harvested on October 6, with a mean density of 65,000 plants ha $^{-1}$. The specific rates of fertilizer application for corn were as follows: urea $(46 \% \mathrm{~N})$, $300 \mathrm{~kg} \mathrm{ha}^{-1}$ (75 $\mathrm{kg} \mathrm{ha}^{-1}$ sowing and $225 \mathrm{~kg} \mathrm{ha}^{-1}$ topdressing); diammonium phosphate $\left(18 \% \mathrm{~N}\right.$ and $\left.46 \% \mathrm{P}_{2} \mathrm{O}_{5}\right), 150 \mathrm{~kg} \mathrm{ha}^{-1}$; and potassium sulfate $\left(30 \% \mathrm{~K}_{2} \mathrm{O}\right), 75 \mathrm{~kg} \mathrm{ha}^{-1}$. The Kenfeng 16 soybean (Glycine max) cultivar was mechanically sown on 
Table 1 Principal chemical properties of the experimental soil

\begin{tabular}{lllllllll}
\hline $\begin{array}{l}\text { Soil } \\
\text { depth } \\
(\mathrm{cm})\end{array}$ & $\begin{array}{l}\text { Organic matter } \\
\left(\mathrm{g} \mathrm{kg}^{-1}\right)\end{array}$ & $\begin{array}{l}\text { Total nitrogen } \\
\left(\mathrm{g} \mathrm{kg}^{-1}\right)\end{array}$ & $\begin{array}{l}\text { Total } \\
\text { phosphorus }(\mathrm{g} \\
\left.\mathrm{kg}^{-1}\right)\end{array}$ & $\begin{array}{l}\text { Total } \\
\text { potassium }(\mathrm{g} \\
\left.\mathrm{kg}^{-1}\right)\end{array}$ & $\begin{array}{l}\mathrm{NO}_{3}^{-}-\mathrm{N} \\
\left(\mathrm{mg} \mathrm{kg}^{-1}\right)\end{array}$ & $\begin{array}{l}\mathrm{NH}_{4}^{+}-\mathrm{N} \\
\left(\mathrm{mg} \mathrm{kg}^{-1}\right)\end{array}$ & $\begin{array}{l}\text { Available } \\
\text { phosphorus }(\mathrm{mg} \\
\left.\mathrm{kg}^{-1}\right)\end{array}$ & $\begin{array}{l}\text { Available } \\
\text { potassium }(\mathrm{mg} \\
\left.\mathrm{kg}^{-1}\right)\end{array}$ \\
\hline $0-20$ & 30.71 & 1.48 & 0.40 & 16.28 & 78.79 & 26.04 & 23.63 & 187.00 \\
\hline
\end{tabular}

May 2 and harvested on September 28 with a seeding rate of $43.66 \mathrm{~kg} \mathrm{ha}^{-1}$ and a mean density of $269,500 \mathrm{plants} \mathrm{ha}^{-1}$. The rates of fertilizer application for soybean were as follows: diammonium phosphate $\left(18 \% \mathrm{~N}\right.$ and $\left.46 \% \mathrm{P}_{2} \mathrm{O}_{5}\right), 150 \mathrm{~kg}$ $\mathrm{ha}^{-1}$, and potassium sulfate $\left(30 \% \mathrm{~K}_{2} \mathrm{O}\right), 75 \mathrm{~kg} \mathrm{ha}^{-1}$. For chemical weeding, 96\% emulsifiable concentrate of Dual Gold mixed with $72 \%$ emulsifiable concentrate of 2,4-D butyl ester was applied for closed weed control 1 week after sowing of corn and soybean, with dosages of $975 \mathrm{ml} \mathrm{ha}^{-1}$ and $1125 \mathrm{ml}$ $\mathrm{ha}^{-1}$, respectively. In addition, 55\% Gengjie was sprayed at the four-to-five leaf stage of corn at a dosage of $1575 \mathrm{ml} \mathrm{ha}^{-1}$, and $36 \%$ fomesafen-quizalofop-p-ethyl-clomazone was sprayed on soybean plants after the development of one to three compound leaves at a dosage of $1650 \mathrm{ml} \mathrm{ha}^{-1}$.

\section{Calculation of cropland CF}

The system boundary of cropland $\mathrm{CF}$ was determined following the principles of LCA (Mohammadi et al. 2013), as shown schematically in Fig. 1. The carbon flux changes of the elements in the carbon cycle of the system were determined and calculated according to the $\mathrm{CF}$ equation developed by Liu et al. (2013); She et al. (2017); and Feng et al. (2020). The CF was calculated as follows:
$C F=G W P_{\mathrm{N}_{2} \mathrm{O}}+G W P_{\text {input }}$

where $\mathrm{CF}$ is the total carbon emissions of crop production, $\mathrm{GWP}_{\mathrm{N}_{2} \mathrm{O}}$ is the total emissions produced by synthetic nitrogen fertilizer and crop residual nitrogen $\left(\mathrm{kg} \mathrm{CO}_{2} \mathrm{ha}^{-1}\right.$ year $\left.{ }^{-1}\right)$, and $\mathrm{GWP}_{\text {input }}$ is the indirect GHG emissions from the production, storage, transportation, and use of agricultural inputs.

$\mathrm{GWP}_{\mathrm{N}_{2} \mathrm{O}}$ emissions were estimated based on the levels of synthetic nitrogen fertilizer and crop residual nitrogen by the method determined by the IPCC (2019). GWP $\mathrm{N}_{2} \mathrm{O}$ emissions were calculated as follows:

$$
\begin{aligned}
\mathrm{GWP}_{\mathrm{N}_{2} \mathrm{O}}= & G W P_{N_{2} O_{S N F}}+G W P_{N_{2} O_{C R N}} \\
\operatorname{GWP}_{N_{2} O_{S N F}}= & Q_{S N F} \times\left[E F+\left(F_{\text {volatilization }} \times \mathrm{E}_{\text {volatilization }}\right)+\left(F_{\text {leach }} \times \mathrm{E}_{\text {leach }}\right)\right] \\
& \times 44 / 28 \times 298 \\
\mathrm{GWP}_{\mathrm{N}_{2} \mathrm{O}}= & Q_{C R N} \times\left[E F+\left(F_{\text {leach }} \times \mathrm{E}_{\text {leach }}\right)\right] \times 44 / 28 \\
& \times 298
\end{aligned}
$$

where $\mathrm{GWP}_{\mathrm{N}_{2} \mathrm{O}_{S N F}}$ represents $\mathrm{N}_{2} \mathrm{O}$ emissions from farmland resulting from synthetic nitrogen fertilizer application $(\mathrm{kg}$ $\mathrm{CO}_{2}$ ha $^{-1}$ year $^{-1}$ ), $\mathrm{GWP}_{\mathrm{N}_{2} \mathrm{O}_{\text {CRN }}}$ represents $\mathrm{N}_{2} \mathrm{O}$ emissions from crop residual nitrogen $\left(\mathrm{kg} \mathrm{CO}_{2} \mathrm{ha}^{-1}\right.$ year $\left.^{-1}\right), Q_{S N F}$ represents the amount of synthetic nitrogen fertilizer $\left(\mathrm{kg} \mathrm{N} \mathrm{ha}^{-1}\right.$
Fig. 1 System boundary for calculating GHG emissions in continuous corn cropping and corn-soybean rotation cropping systems

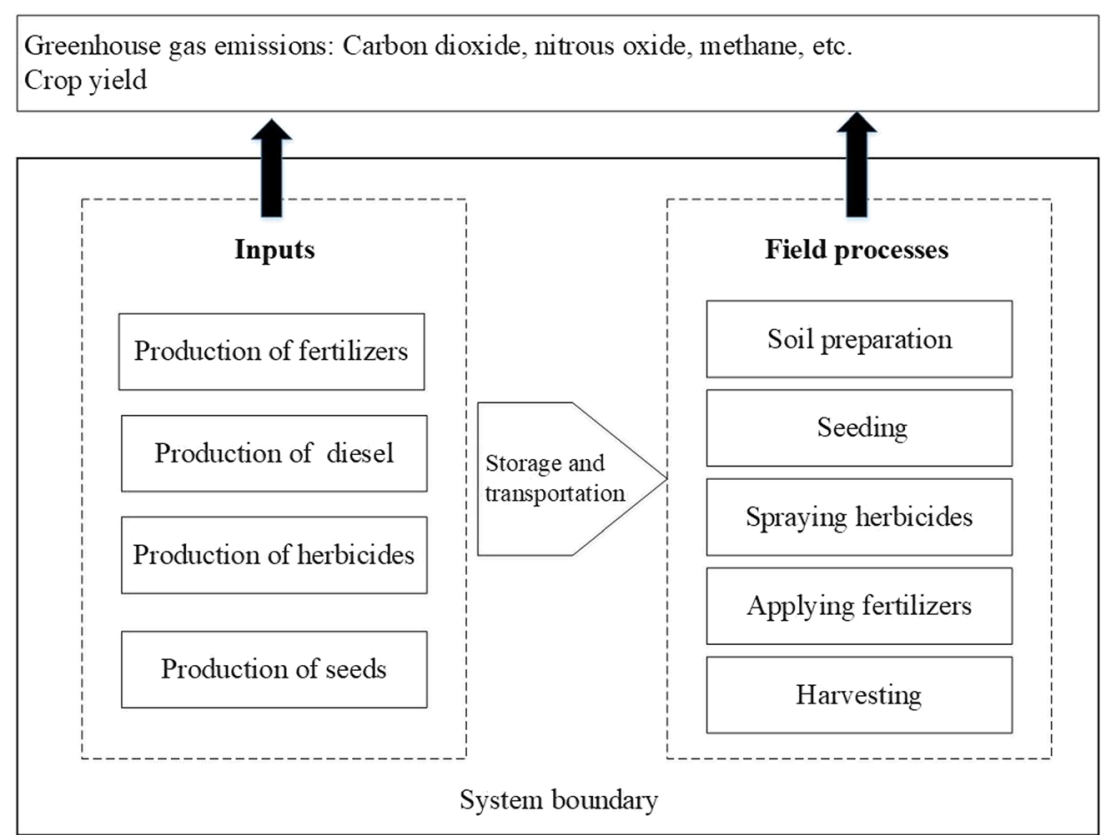


year $\left.^{-1}\right), Q_{C R N}$ represents the crop residue nitrogen $\left(\mathrm{kg} \mathrm{N}^{-1}\right.$ year $\left.^{-1}\right), E F$ is the direct emission factor $\left(\mathrm{kg} \mathrm{N}_{2} \mathrm{O}-\mathrm{N} / \mathrm{kg} \mathrm{N}\right.$, $0.01), \mathrm{F}_{\text {volatilization }}$ is the rate of volatilization of synthetic nitrogen fertilizer as $\mathrm{NH}_{3}-\mathrm{N}$ and $\mathrm{NO}_{\mathrm{x}}-\mathrm{N}(15 \%), \mathrm{E}_{\text {volatilization }}$ is the emission factor for $\mathrm{N}_{2} \mathrm{O}$ volatilized as $\mathrm{NH}_{3}-\mathrm{N}$ and $\mathrm{NO}_{\mathrm{x}}-\mathrm{N}$ (0.014), $\mathrm{F}_{\text {leach }}$ is the percent nitrogen loss via nitrate leaching and runoff in the total nitrogen input $(24 \%), \mathrm{E}_{\text {leach }}$ is the emission factor for $\mathrm{N}_{2} \mathrm{O}$ from nitrate leaching (0.011), 44/28 is the conversion factor for $\mathrm{N}_{2} \mathrm{O}-\mathrm{N}$ to $\mathrm{N}_{2} \mathrm{O}$, and 298 is the global warming potential of $\mathrm{N}_{2} \mathrm{O}$ over a 100 -year period (Yang et al. 2014; IPCC 2019; Wang et al. 2020).

$\mathrm{GWP}_{\text {input }}$ is the $\mathrm{CO}_{2}$ emissions from agricultural inputs during agricultural production, calculated as follows:

$\mathrm{GWP}_{\text {input }}=\sum_{\mathrm{i}=1}^{\mathrm{n}} \mathrm{AL}_{\mathrm{i}} \times \mathrm{EF}_{\mathrm{i}}$

where $\mathrm{AL}_{\mathrm{i}}$ is the ith input variable and $\mathrm{EF}_{\mathrm{i}}$ is the emission factor for the ith input variable. The emission factors were mainly derived from Liu et al. (2013) and Yang et al. (2014) (Table 2). Specifically, diesel input was determined by measuring diesel fuel consumption during soil preparation, seeding, intertillage, and harvesting using a multifunction fuel consumption meter (Shuangshuo Electronics Co., Ltd., Zibo, Shandong Province, China). The measurement was performed on a row length of $100 \mathrm{~m}$ and repeated three times. Agricultural chemical inputs were calculated as the amounts of chemical elements according to the inputs reported in the "Experimental design" subsection, and the agricultural inputs are listed in Table 3.

\section{Calculation of cropland carbon balance}

Net biome productivity (NBP) is the change in net carbon storage of the cropland ecosystem, calculated as follows (Huang et al. 2013; She et al. 2017):

$N B P=N P P-C R-R_{S}$

where NPP is net primary productivity, CR is the grain and straw removed with crop harvest, and $R_{s}$ is the heterotrophic soil microbial respiration. NPP includes carbon sequestered

Table 2 Emission factors for agriculture inputs used in the estimation

\begin{tabular}{lll}
\hline & $\left(\mathrm{kg} \mathrm{CO}_{2} \mathrm{ha}^{-1} \mathrm{year}^{-1}\right)$ & Reference \\
\hline $\mathrm{N}$ & 4.96 & (Liu et al. 2013) \\
$\mathrm{P}$ & 1.14 & (Liu et al. 2013) \\
$\mathrm{K}$ & 0.66 & (Liu et al. 2013) \\
Herbicide & 6.58 & (Liu et al. 2013) \\
Corn seeds & 1.22 & (Liu et al. 2013) \\
Soybean seeds & 0.92 & (West and Marland 2002) \\
Diesel & 3.32 & (Liu et al. 2013) \\
\hline
\end{tabular}

by crop grains, straw, and roots. NPP was calculated from measurements of the grain yield at harvest, the dry weight percentages of plant parts, and the carbon content measured in various parts of the plants. CR includes crop grains, stalks, and cobs removed from the field after harvest. Under the STR treatment, only the corn and soybean grains were harvested from the field, while under STM, corn grains, cobs, and stalks and soybean grains, pods, and stalks were all harvested from the field. $R_{S}$ was estimated from the actual field measurement of total soil in situ respiration according to the ratio of heterotrophic respiration to total in situ respiration for the same area as reported by Zhu (2015) (65\% for corn and $76 \%$ for soybean) (Table 4 ).

The total soil in situ respiration was measured using the static box-infrared gas analyzer method. Gas samples were collected every 7 to 10 days from April 5 to November 8 . Sampling boxes were made of stainless steel, $50 \mathrm{~cm}$ long, $25 \mathrm{~cm}$ wide, and $50 \mathrm{~cm}$ high. Gas samples were collected between 8:30 and 10:30 am on sunny days. Five sampling sites were randomly selected in the treatment plots. Sampling boxes were inserted between two ridges and sealed with approximately $5 \mathrm{~cm}$ of soil, and gas was then transferred into 500-ml aluminum foil bags using a 100-ml glass syringe. The $\mathrm{CO}_{2}$ concentration was determined using a GXH-3010E1 infrared analyzer (Institute of Beijing HUAYUN Analytical Instrument Co., Ltd.).

The $\mathrm{CB}$ of cropland was used to indicate the difference between the CF and NBP as follows:

$C B=N B P-C F$

\section{Statistical analysis}

The data were analyzed using descriptive statistics in Microsoft Excel 2016 (Microsoft Corp., Redmond, WA, USA) and IBM SPSS 19.0 (SPSS Inc., Chicago, IL, USA). The results included the means and standard deviations (SD) of three replicates, and Duncan's multiple range test was used at a significance level of $P<0.05$.

\section{Results and analysis}

\section{CF of cropland under different cropping patterns}

The $\mathrm{CO}_{2}$-equivalent emissions estimated based on $\mathrm{N}_{2} \mathrm{O}$ produced by nitrogen fertilizer and straw application were the greatest contributors to the CF (Fig. 2). The percentage of direct $\mathrm{N}_{2} \mathrm{O}$ emissions to total emissions was as follows: $58 \%$ for CC-STR, $51 \%$ for CC-STM, 55\% for CS-STR, and $48 \%$ for CS-STM. STR resulted in higher $\mathrm{N}_{2} \mathrm{O}$ emissions from both the $\mathrm{CC}$ and $\mathrm{CS}$ systems. The second greatest contributor was 
Table 3 Average agricultural inputs for crops $\left(\mathrm{kg} \mathrm{ha}^{-1} \mathrm{year}^{-1}\right)$

\begin{tabular}{|c|c|c|c|c|c|}
\hline & & \multicolumn{2}{|l|}{ Corn } & \multicolumn{2}{|l|}{ Soybean } \\
\hline & & Straw retention & Straw removal & Straw retention & Straw removal \\
\hline \multirow[t]{6}{*}{ Diesel } & Soil preparation & 8.57 & 25.35 & 8.57 & 25.35 \\
\hline & Seeding & 5.09 & 6.26 & 5.47 & 5.49 \\
\hline & Spraying herbicides & 1.70 & 2.09 & 1.82 & 1.83 \\
\hline & Intertillage & 8.88 & 9.23 & 9.16 & 9.52 \\
\hline & Topdressing & 5.09 & 6.26 & & \\
\hline & Harvest & 25.00 & 25.00 & 20.00 & 20.00 \\
\hline \multirow[t]{5}{*}{ Agricultural inputs } & $\mathrm{N}$ & 165.00 & 165.00 & 27.00 & 27.00 \\
\hline & $\mathrm{P}$ & 69.00 & 69.00 & 69.00 & 69.00 \\
\hline & $\mathrm{K}$ & 22.50 & 22.50 & 22.50 & 22.50 \\
\hline & Herbicide & 2.61 & 2.61 & 2.30 & 2.30 \\
\hline & Seeds & 18.75 & 18.75 & 43.66 & 43.66 \\
\hline
\end{tabular}

indirect $\mathrm{CO}_{2}$ emissions from the production, storage, and transportation of nitrogen fertilizer, accounting for $30 \%$ and $34 \%$ of total emissions from CC and $28 \%$ and $29 \%$ of total emissions from CS. In addition, diesel consumption by agricultural machinery operations from sowing to harvesting produced considerable carbon emissions. In both CC and CS, carbon emissions from diesel consumption were higher under STM (226-246 kg CO $\mathrm{ha}^{-1}$ year $^{-1}$ ) than under STR (165$180 \mathrm{~kg} \mathrm{CO}_{2}$ ha $^{-1}$ year $^{-1}$ ).

The CF of CC was higher than that of CS (Table 5). Due to the large amount of nitrogen in crop straw, the $\mathrm{CF}$ of CC with STR $\left(2707 \mathrm{~kg} \mathrm{CO}_{2} \mathrm{ha}^{-1}\right.$ year $\left.{ }^{-1}\right)$ was $11 \%$ higher than that of CC with STM (2434 $\mathrm{kg} \mathrm{CO}_{2} \mathrm{ha}^{-1}$ year $^{-1}$ ) and 6\% higher under CS.

\section{Soil heterotrophic respiration under different cropping patterns}

The total soil heterotrophic respiration of $\mathrm{CC}$ was similar to that of CS (Fig. 3). Total emissions ranged from 5139 to $7493 \mathrm{~kg} \mathrm{CO}_{2}$ eq ha ${ }^{-1}$ year $^{-1}$ under CC and from 5072 to $6902 \mathrm{~kg} \mathrm{CO}_{2}$ eq ha ${ }^{-1}$ year $^{-1}$ under CS. STR significantly increased total heterotrophic respiration by $46 \%$ under CC and $36 \%$ under CS compared with STM $(p<0.05)$.

\section{NPP under different treatments}

Corn with higher grain yield produced more biomass and NPP than did soybean, leading to differences in yield, biomass, and

Table 4 Yield, biomass, and NPP under different modes

\begin{tabular}{|c|c|c|c|c|c|c|c|}
\hline \multicolumn{2}{|c|}{ Agricultural system } & \multicolumn{2}{|l|}{ Yield $\left(\mathrm{kg} \mathrm{ha}^{-1}\right)^{\mathrm{a}}$} & \multicolumn{2}{|c|}{ Biomass $\left(\mathrm{kg} \mathrm{ha}^{-1}\right)^{\mathrm{b}}$} & \multicolumn{2}{|l|}{$\operatorname{NPP}\left(\mathrm{kg} \mathrm{C} \mathrm{ha}{ }^{-1}\right)^{\mathrm{c}}$} \\
\hline Year & Crop & Straw retention & Straw removal & Straw retention & Straw removal & Straw retention & Straw removal \\
\hline 2013 & Corn & $9185 b$ & $10,624 a$ & 20,231 & 23,402 & 9534 & 11,028 \\
\hline 2014 & Corn & $13,426 \mathrm{a}$ & $11,948 \mathrm{a}$ & 29,572 & 26,316 & 13,935 & 12,401 \\
\hline 2014 & Soybean & $2275 b$ & $2938 \mathrm{a}$ & 6438 & 8314 & 2760 & 3563 \\
\hline \multicolumn{2}{|c|}{ Continuous corn croppingd } & 11,305 & 11,286 & 24,901 & 24,859 & 11,734 & 11,714 \\
\hline \multicolumn{2}{|c|}{ Corn-soybean rotationd } & 5730 & 6781 & 13,335 & 15,858 & 6147 & 7295 \\
\hline
\end{tabular}

${ }^{a}$ Differing lowercase letters for horizontal comparisons indicate significant differences between the treatments for the same crop $(p<0.05)$

${ }^{\mathrm{b}}$ Biomass of corn and soybean converted from grain yield. The dry-weight percentages of various parts of the corn plants were as follows: grains, $45.4 \%$; roots, $9.4 \%$; stalks, $38.3 \%$; and cobs, $6.9 \%$. The dry-weight percentages of various parts of the soybean plants were as follows: grains, $35.3 \%$; roots, $5.2 \%$; stalks, $18.6 \%$; petioles, $25.0 \%$; and pod walls, $15.8 \%$

${ }^{\mathrm{c}} \mathrm{NPP}$ was calculated from the grain yield and the dry weight percentages and carbon contents of various parts of corn and soybean plants. The carbon contents of various parts of corn plants were as follows: grains, $48.9 \%$; roots, $46.5 \%$; stalks, $45.3 \%$; and cobs, $46.4 \%$. The carbon contents of various parts of soybean plants were as follows: grains, $42.6 \%$; roots, $46.8 \%$; stalks, $47.9 \%$; petioles, $38.0 \%$; and pod walls, $43.9 \%$

${ }^{\mathrm{d}}$ The grain yield, biomass, and NPP for continuous corn cropping are mean values for corn in 2013 and 2014. The grain yield, biomass, and NPP for the corn-soybean rotation are the mean values for corn in 2013 and for soybeans in 2014 

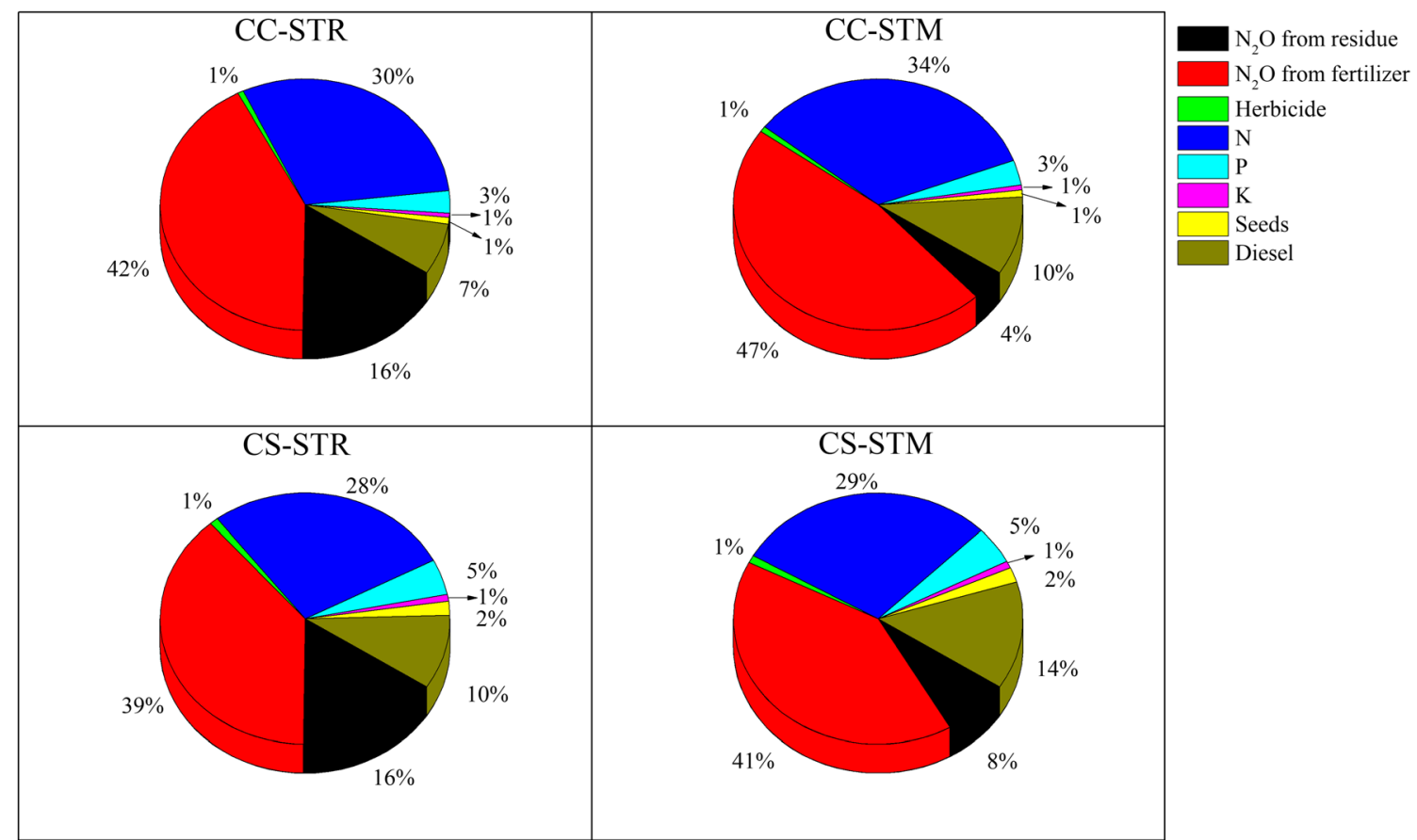

Fig. 2 Shares of different inputs in the carbon footprints of continuous corn cropping and corn-soybean rotation cropping systems (two-season averages)

NPP under different cropping patterns. CC produced significantly higher crop yields than CS. STR significantly reduced soybean yield, while its effect on corn yield was not significant compared with that of STM. Overall, STR resulted in lower values for yield, biomass, and NPP in the CS system (Table 4).

\section{CB of cropland under different cropping patterns}

The NBP of the CC and CS systems with STR were 12,339 and $4436 \mathrm{~kg} \mathrm{CO}_{2} \mathrm{ha}^{-1}$ year $^{-1}$, respectively, and the NBP of CC-STR was $178 \%$ higher than that of CS-STR. The CB of cropland was also positive, with annual carbon sequestrations of 9633 and $2716 \mathrm{~kg} \mathrm{CO}_{2}$ ha $^{-1}$ year $^{-1}$, respectively. The CB of CC-STR was $225 \%$ higher than that of CS-STR. In contrast, NBP was negative for the CC and CS systems with STM, with values of
-1155 and $-1376 \mathrm{~kg} \mathrm{CO}_{2} \mathrm{ha}^{-1}$ year ${ }^{-1}$, respectively. For $\mathrm{CO}_{2^{-}}$ equivalents from soil $\mathrm{N}_{2} \mathrm{O}$ and agricultural inputs, there were strong GHG emissions effects, with annual releases of -3589 and $-3006 \mathrm{~kg} \mathrm{CO}_{2}$-equivalents $\mathrm{ha}^{-1}$ year $^{-1}$, respectively. These results indicate that straw retention plays a significant role in carbon sequestration under both the CC and CS systems.

\section{Discussion}

\section{Variations in CF under different cropping patterns}

Inputs and outputs of agricultural ecosystems vary with cropping pattern, leading to differences in CF (Gan et al. 2012; Yang et al. 2014; Wang et al. 2020). Our study also

Table 5 CF, NBP, and CB of cropland under different cropping patterns

\begin{tabular}{|c|c|c|c|c|c|c|c|}
\hline \multicolumn{2}{|c|}{ Agricultural system } & \multicolumn{2}{|c|}{$\mathrm{CF}\left(\mathrm{kg} \mathrm{CO}_{2} \mathrm{ha}^{-1}\right.$ year $\left.^{-1}\right)$} & \multicolumn{2}{|c|}{$\mathrm{NBP}\left(\mathrm{kg} \mathrm{CO}_{2} \mathrm{ha}^{-1}\right.$ year $\left.^{-1}\right)$} & \multicolumn{2}{|c|}{$\mathrm{CB}^{\mathrm{a}}\left(\mathrm{kg} \mathrm{CO}_{2} \mathrm{ha}^{-1}\right.$ year $\left.^{-1}\right)$} \\
\hline Year & Crop & Straw retention & Straw removal & Straw retention & Straw removal & Straw retention & Straw removal \\
\hline 2013 & Corn & 2625 & 2428 & 8697 & -2351 & 6071 & -4780 \\
\hline 2014 & Corn & 2789 & 2440 & 15,982 & 41 & 13,193 & -2399 \\
\hline 2014 & Soybean & 816 & 832 & 176 & -401 & -639 & -1233 \\
\hline \multicolumn{2}{|c|}{ Continuous corn cropping ${ }^{\mathrm{b}}$} & 2707 & 2434 & 12,339 & -1155 & 9633 & -3589 \\
\hline \multicolumn{2}{|c|}{ Corn-soybean rotationb } & 1721 & 1630 & 4436 & -1376 & 2716 & -3006 \\
\hline
\end{tabular}

${ }^{\text {a }} \mathrm{A}$ positive value for $\mathrm{CB}$ indicates that the system is a sink for atmospheric $\mathrm{CO}_{2}$, while a negative value for $\mathrm{CB}$ indicates that the system is a source for atmospheric $\mathrm{CO}_{2}$

${ }^{\mathrm{b}} \mathrm{CF}, \mathrm{NBP}$, and $\mathrm{CB}$ for continuous corn cropping are the mean values for corn in 2013 and 2014. The CF, NBP, and CB for corn-soybean rotation are the mean values for corn in 2013 and for soybeans in 2014 


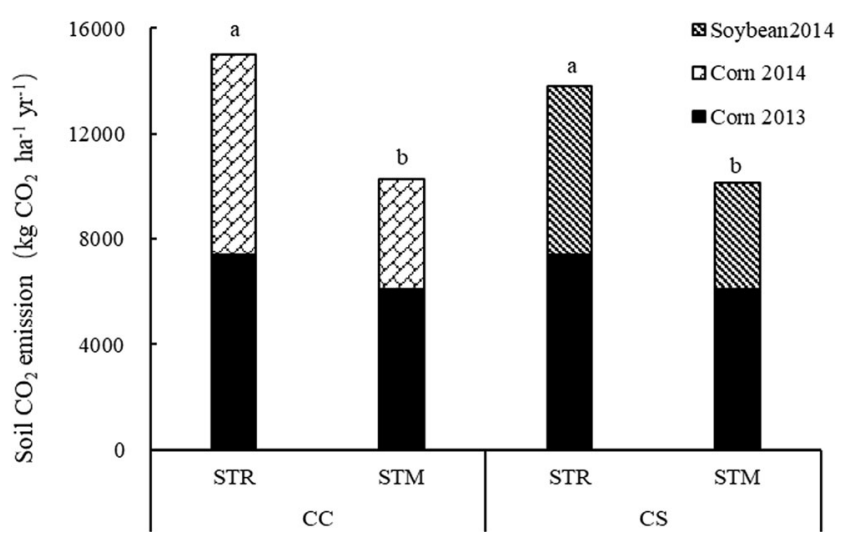

Fig. 3 Soil heterotrophic respiration under different cropping patterns

obtained similar results; the inputs of nitrogen fertilizer, diesel fuel, and straw were higher for CC than for CS, resulting in a higher CF with CC than with CS. Similar results were reported by Yadav et al. (2018) and Lal et al. (2019).

$\mathrm{N}_{2} \mathrm{O}$ emissions were the greatest contributor to the total $\mathrm{CF}$, followed by indirect $\mathrm{N}_{2} \mathrm{O}$ emissions from nitrogen fertilizer production, storage, and transportation. This result agrees with the findings of Yadav et al. (2018). However, Jat et al. (2019) and Lal et al. (2019) reported that fertilizer application makes the greatest contribution, followed by $\mathrm{N}_{2} \mathrm{O}$ emissions and diesel emissions. Our findings were not entirely consistent with these results. These conflicting results may be explained by noting that Jat et al. (2019) and Lal et al. (2019) did not consider $\mathrm{N}_{2} \mathrm{O}$ volatilization and leaching.

Despite differences in these studies, they all demonstrate that indirect $\mathrm{N}_{2} \mathrm{O}$ emissions from the production, storage, and transportation of nitrogen fertilizer as well as direct $\mathrm{N}_{2} \mathrm{O}$ emissions from the application of nitrogen fertilizer are the most important components of total GHG emissions from crop production (Hillier et al. 2009a; Cheng et al. 2011; West et al. 2014; Wang et al. 2020). Therefore, reducing nitrogen fertilizer input and adopting a sustainable application method are crucial practices to mitigate agricultural GHG emissions from fertilizer application (Bacenetti et al. 2016; Feng et al. 2020). It should be noted that reducing nitrogen fertilizer may affect yield and that the amount of nitrogen fertilizer should be adjusted by comprehensively considering $\mathrm{CF}$ changes per unit of yield. In this study, diesel input was the third highest contributor to the CF (7-14\%). During soil preparation, minimal tillage and no-tillage with reduced agricultural machinery operation can reduce GHG emissions (Yadav et al. 2018).

\section{Carbon balance of cropland under different cropping patterns}

Carbon sequestration and carbon emissions are two processes that coexist in agricultural production. GHGs such as $\mathrm{CO}_{2}$ and $\mathrm{N}_{2} \mathrm{O}$ are directly or indirectly emitted into the atmosphere, while plants absorb atmospheric $\mathrm{CO}_{2}$ through photosynthesis
(Soussana et al. 2007; Smith et al. 2010; Liu et al. 2018; Feng et al. 2020). The CB of cropland can directly characterize changes in net carbon flow in cropland systems (Feng et al. 2020). Generally, if all crop straw is returned to the farmland, then it is equivalent to the amount of GHG released after the straw is decomposed. Therefore, neither straw carbon sequestration nor straw carbon emissions are considered in general (Feng et al. 2020). However, our study aimed to assess the effects of STR and STM on the CB of cropland under two different cropping patterns; thus, crop straw inputs were considered. Although this approach may exaggerate the carbon sequestration effect of STR, the carbon sequestration trend was clear. Huang et al. (2019) obtained CFs based on changes in soil organic carbon storage in Jilin Province, showing that net carbon sequestration was $745 \mathrm{~kg} \mathrm{CO}_{2} \mathrm{ha}^{-1}$ year $^{-1}$ under CC with minimal tillage and STR. In our study, following straw retention, the carbon sequestered by $\mathrm{CC}$ was $9633 \mathrm{~kg} \mathrm{CO}_{2} \mathrm{ha}^{-1}$ year $^{-1}$, and the carbon sequestered by CS was $2716 \mathrm{~kg} \mathrm{CO}_{2} \mathrm{ha}^{-1}$ year $^{-1}$. The carbon sequestration of CC reported here is higher than that reported by Huang et al. (2019), but this result may reflect the carbon sequestration effect of straw return. Due to differences in study methods and boundaries, discrepancies exist in results obtained from the same region by different researchers, but the data all reflect the advantage of straw retention for carbon sequestration. Lemke et al. (2010) and Huang et al. (2019) reported that if there is not enough crop straw to return, cropland soil will become a $\mathrm{CO}_{2}$ source. Our study reaches a similar conclusion. Both cropping patterns were a source of atmospheric $\mathrm{CO}_{2}$ under STM.

\section{Limitations and implications of this study}

This study ignores GHG emissions from agricultural labor and agricultural machinery manufacturing, transportation, maintenance, and management. From the life cycle perspective, these GHG emissions are not negligible (Liu et al. 2013). If these factors are considered in CF calculations, the absolute value of the CF may change. This study compared the effects of differences in planting pattern and straw utilization on the $\mathrm{CF}$ to determine the most favorable planting pattern rather than obtaining absolute values for the CF of planting patterns. Although the calculation method employed in this paper requires improvement, it can provide a basis for further research and guide low-carbon agricultural production and is relevant to national carbon emission and environmental impact assessments.

\section{Conclusions}

STR greatly impacted GHG emissions, $\mathrm{CF}$, and $\mathrm{CB}$. The $\mathrm{CF}$ was higher for $\mathrm{CC}$ than for $\mathrm{CS}$, and nitrogen fertilizer was the 
most important factor affecting the $\mathrm{CF}$. When considering the carbon fixed by crops, the CB of the STR treatment was positive for $\mathrm{CC}$ and $\mathrm{CS}$. Crop yield and $\mathrm{CB}$ were higher in $\mathrm{CC}$ STR than in CS-STR. Straw return in CC can promote high yield and low carbon emissions, provide improved ecological benefits, and accelerate clean and sustainable production in the Songnen Plain of Northeast China.

Author contribution QS established the goal of the study, analyzed the data related to carbon footprints, and was a major contributor to the writing of the manuscript. JZ performed the gas collection in the field. ZG guided the entire study and was a major contributor to the writing of the manuscript. YF conducted the literature retrieval work. QW analyzed the data on carbon balance. YS analyzed and explained the data on carbon emissions from diesel fuel. XZ analyzed and explained the data on indirect carbon emissions from fertilizer. YL analyzed and explained the data related to carbon footprints. All authors read and approved the final manuscript.

Funding This research was supported by the National Natural Science Foundation of China (No. 31901473) and the Agricultural Science and Technology Innovation Leaping Project of Heilongjiang Academy of Agricultural Sciences in China (No. HNK2019CX12).

Availability of data and materials The datasets used and/or analyzed during the current study are available from the corresponding author on reasonable request.

All data generated or analyzed during this study are included in this published article and its supplementary information files.

\section{Declarations}

Ethics approval and consent to participate Not applicable.

\section{Consent for publication Not applicable.}

Competing interests The authors declare no competing interests.

Open Access This article is licensed under a Creative Commons Attribution 4.0 International License, which permits use, sharing, adaptation, distribution and reproduction in any medium or format, as long as you give appropriate credit to the original author(s) and the source, provide a link to the Creative Commons licence, and indicate if changes were made. The images or other third party material in this article are included in the article's Creative Commons licence, unless indicated otherwise in a credit line to the material. If material is not included in the article's Creative Commons licence and your intended use is not permitted by statutory regulation or exceeds the permitted use, you will need to obtain permission directly from the copyright holder. To view a copy of this licence, visit http://creativecommons.org/licenses/by/4.0/.

\section{References}

Adewale C, Reganold JP, Higgins S, Evans RD, Carpenter-Boggs L (2019) Agricultural carbon footprint is farm specific: case study of two organic farms. J Clean Prod 229:795-805. https://doi.org/10. 1016/j.jclepro.2019.04.253
Bacenetti J, Lovarelli D, Fiala M (2016) Mechanisation of organic fertiliser spreading, choice of fertiliser and crop residue management as solutions for maize environmental impact mitigation. Eur J Agron 79:107-118. https://doi.org/10.1016/j.eja.2016.05.015

Bai J, Li Y, Zhang J, Xu F, Bo Q, Wang Z, Li Z, Li S, Shen Y, Yue S (2021) Straw returning and one-time application of a mixture of controlled release and solid granular urea to reduce carbon footprint of plastic film mulching spring maize. J Clean Prod 280. https://doi. org/10.1016/j.jclepro.2020.124478

Bennetzen EH, Smith P, Porter JR (2016) Agricultural production and greenhouse gas emissions from world regions - the major trends over 40 years. Glob Environ Chang 37:43-55. https://doi.org/10. 1016/j.gloenvcha.2015.12.004

Cheng K, Pan G, Smith P, Luo T, Li L, Zheng J, Zhang X, Han X, Yan M (2011) Carbon footprint of China's crop production - an estimation using agro-statistics data over 1993-2007. Agric Ecosyst Environ 142:231-237. https://doi.org/10.1016/j.agee.2011.05.012

Clay DE, Chang J, Clay SA, Stone J, Gelderman RH, Carlson GC, Reitsma K, Jones M, Janssen L, Schumacher T (2012) Corn yields and no-tillage affects carbon sequestration and carbon footprints. Agron J 104:763-770. https://doi.org/10.2134/agronj2011.0353

Duan H, Yue Z, Jianbo Z, Xinmin B (2011) Carbon footprint analysis of farmland ecosystem in China. J Soil Water Conserv 25:203-208 (In Chinese)

Feng Y, Zhang Y, Li S, Wang C, Yin X, Chu Q, Chen F (2020) Sustainable options for reducing carbon inputs and improving the eco-efficiency of smallholder wheat-maize cropping systems in the Huanghuaihai Farming Region of China. J Clean Prod 244:118887. https://doi.org/10.1016/j.jclepro.2019.118887

Gan Y, Liang C, Campbell CA, Zentner RP, Lemke RL, Wang H, Yang C (2012) Carbon footprint of spring wheat in response to fallow frequency and soil carbon changes over 25 years on the semiarid Canadian prairie. Eur J Agron 43:175-184. https://doi.org/10.1016/ j.eja.2012.07.004

Gan Y, Liang C, Chai Q, Lemke RL, Campbell CA, Zentner RP (2014) Improving farming practices reduces the carbon footprint of spring wheat production. Nat Commun 5:1-13. https://doi.org/10.1038/ ncomms 6012

Günther J, Thevs N, Gusovius H-J, Sigmund I, Brückner T, Beckmann V, Abdusalik N (2017) Carbon and phosphorus footprint of the cotton production in Xinjiang, China, in comparison to an alternative fibre (Apocynum) from Central Asia. J Clean Prod 148:490-497. https:// doi.org/10.1016/j.jclepro.2017.01.153

Heusala H, Sinkko T, Sözer N, Hytönen E, Mogensen L, Knudsen MT (2020) Carbon footprint and land use of oat and faba bean protein concentrates using a life cycle assessment approach. J Clean Prod 242:118376. https://doi.org/10.1016/j.jclepro.2019.118376

Hillier J, Hawes C, Squire G, Hilton A, Wale S, Smith P (2009a) The carbon footprints of food crop production. Int J Agric Sustain 7: 107-118. https://doi.org/10.3763/ijas.2009.0419

Hillier J et al (2009b) Greenhouse gas emissions from four bioenergy crops in England and Wales: integrating spatial estimates of yield and soil carbon balance in life cycle analyses. Glob Change Biol Bioenergy 1:267-281. https://doi.org/10.1111/j.1757-1707.2009. 01021.x

Houshyar E, Grundmann P (2017) Environmental impacts of energy use in wheat tillage systems: a comparative life cycle assessment (LCA) study in Iran. Energy 122:11-24. https://doi.org/10.1016/j.energy. 2017.01.069

Huang J, Chen Y, Sui P, Gao W (2013) Estimation of net greenhouse gas balance using crop-and soil-based approaches: two case studies. Sci Total Environ 456:299-306. https://doi.org/10.1016/j.scitotenv. 2013.03.035

Huang J, Chen Y, Pan J, Liu W, Yang G, Xiao X, Zheng H, Tang W, Tang H, Zhou LJ (2019) Carbon footprint of different agricultural 
systems in China estimated by different evaluation metrics. J Clean Prod 225:939-948. https://doi.org/10.1016/j.jclepro.2019.04.044

IPCC (2013) Summary for policymakers. In: Climate Change 2013: the physical science basis. Contribution of Working Group I to the Fifth Assessment Report of the Intergovernmental Panel on Climate Change. In: Stocker TF, D. Qin, G.-K. Plattner, M. Tignor, S.K. Allen, J. Boschung, A. Nauels, Y. Xia, V. Bex and P.M. Midgley (eds) Cambridge University Press, Cambridge, United Kingdom and New York, NY, USA

IPCC (2019) 2019 Refinement to the 2006 IPCC Guidelines for National Greenhouse Gas Inventories. In: Kristell Hergoualc'h HA, Martial Bernoux, Ngonidzashe Chirinda, Agustin del Prado, Åsa Kasimir, James Douglas MacDonald, Stephen Michael Ogle, Kristiina Regina, Tony John van der Weerden (eds) Agriculture, Forestry and Other Land Use. IPCC, Switzerland

Jat SL, Parihar CM, Singh AK, Kumar B, Choudhary M, Nayak HS, Parihar MD, Parihar N, Meena BR (2019) Energy auditing and carbon footprint under long-term conservation agriculture-based intensive maize systems with diverse inorganic nitrogen management options. Sci Total Environ 664:659-668. https://doi.org/10.1016/j. scitotenv.2019.01.425

Lal R (2004) Carbon emission from farm operations. Environ Int 30:981990. https://doi.org/10.1016/j.envint.2004.03.005

Lal B, Gautam P, Nayak AK, Panda BB, Bihari P, Tripathi R, Shahid M, Guru PK, Chatterjee D, Kumar U, Meena BP (2019) Energy and carbon budgeting of tillage for environmentally clean and resilient soil health of rice-maize cropping system. J Clean Prod 226:815830. https://doi.org/10.1016/j.jclepro.2019.04.041

Larsen HN, Hertwich EG (2011) Analyzing the carbon footprint from public services provided by counties. J Clean Prod 19:1975-1981. https://doi.org/10.1016/j.jclepro.2011.06.014

Lemke RL, VandenBygaart AJ, Campbell CA, Lafond GP, Grant B (2010) Crop residue removal and fertilizer N: effects on soil organic carbon in a long-term crop rotation experiment on a Udic Boroll. Agric Ecosyst Environ 135:42-51. https://doi.org/10.1016/j.agee. 2009.08.010

Li L et al (2002) Correlations between plant biomass and soil respiration in a Leymus chinensis community in the Xilin River Basin of Inner Mongolia. Acta Bot Sin 44:593-597

Li SH, Guo LJ, Cao CG, Li CF (2020) Effects of straw returning levels on carbon footprint and net ecosystem economic benefits from ricewheat rotation in central China. Environ Sci Pollut Res Int 28: 5742-5754. https://doi.org/10.1007/s11356-020-10914-w

Linquist B, Van Groenigen KJ, Adviento-Borbe MA, Pittelkow C, Van Kessel C (2012) An agronomic assessment of greenhouse gas emissions from major cereal crops. Glob Chang Biol 18:194-209. https:// doi.org/10.1111/j.1365-2486.2011.02502.X

Liu X, Xu W, Li Z, Chu Q, Yang X, Chen F (2013) The missteps, improvement and application of carbon footprint methodology in farmland ecosystems with the case study of analyzing the carbon efficiency of China's Intensive farming. Chin J Agric Resour Reg Plan 34:1-11 (In Chinese)

Liu C, Cutforth H, Chai Q, Gan Y (2016) Farming tactics to reduce the carbon footprint of crop cultivation in semiarid areas. A review. Agron Sustain Dev 36:2-16. https://doi.org/10.1007/s13593-0160404-8

Liu W, Zhang G, Wang X, Lu F, Ouyang Z (2018) Carbon footprint of main crop production in China: magnitude, spatial-temporal pattern and attribution. Sci Total Environ 645:1296-1308. https://doi.org/ 10.1016/j.scitotenv.2018.07.104

Meier EA, Thorburn PJ, Bell LW, Harrison MT, Biggs JS (2020) Greenhouse gas emissions from cropping and grazed pastures are similar: a simulation analysis in Australia. Front Sustain Food Syst 3:1-18. https://doi.org/10.3389/fsufs.2019.00121

Mohammadi A et al (2013) Potential greenhouse gas emission reductions in soybean farming: a combined use of Life Cycle Assessment and
Data Envelopment Analysis. J Clean Prod 54:89-100. https://doi. org/10.1111/j.1365-2486.2011.02502.x

Nelson RG, Hellwinckel CM, Brandt CC, West TO, Dg DLTU, Marland G (2009) Energy use and carbon dioxide emissions from cropland production in the United States, 1990-2004. J Environ Qual 38:418 425. https://doi.org/10.2134/jeq2008.0262

Peters GP (2010) Carbon footprints and embodied carbon at multiple scales. Curr Opin Environ Sustain 2:245-250. https://doi.org/10. 2134/jeq2008.0262

Pishgar-Komleh S, Akram A, Keyhani A, Raei M, Elshout P, Huijbregts M, Van Zelm R (2017) Variability in the carbon footprint of openfield tomato production in Iran-a case study of Alborz and EastAzerbaijan provinces. J Clean Prod 142:1510-1517. https://doi. org/10.1016/j.jclepro.2016.11.154

Röös E, Sundberg C, Hansson PA (2010) Uncertainties in the carbon footprint of food products: a case study on table potatoes. Int $\mathrm{J}$ Life Cycle Assess 15:478-488. https://doi.org/10.1007/s11367010-0171-8

She W, Wu Y, Huang H, Chen Z, Cui G, Zheng H, Guan C, Chen F (2017) Integrative analysis of carbon structure and carbon sink function for major crop production in China's typical agriculture regions. J Clean Prod 162:702-708. https://doi.org/10.1016/j.jclepro.2017. 05.108

Smith P, Lanigan G, Kutsch WL, Buchmann N, Eugster W, Aubinet M, Ceschia E, Béziat P, Yeluripati JB, Osborne B, Moors EJ, Brut A, Wattenbach M, Saunders M, Jones M (2010) Measurements necessary for assessing the net ecosystem carbon budget of croplands. Agric Ecosyst Environ 139:302-315. https://doi.org/10.1016/j. agee.2010.04.004

Soussana JF, Allard V, Pilegaard K, Ambus P, Amman C, Campbell C, Ceschia E, Clifton-Brown J, Czobel S, Domingues R, Flechard C, Fuhrer J, Hensen A, Horvath L, Jones M, Kasper G, Martin C, Nagy Z, Neftel A, Raschi A, Baronti S, Rees RM, Skiba U, Stefani P, Manca G, Sutton M, Tuba Z, Valentini R (2007) Full accounting of the greenhouse gas $(\mathrm{CO} 2, \mathrm{~N} 2 \mathrm{O}, \mathrm{CH} 4)$ budget of nine European grassland sites. Agric Ecosyst Environ 121:121-134. https://doi. org/10.1016/j.agee.2006.12.022

Wang H, Yang Y, Zhang X, Tian G (2015a) Carbon footprint analysis for mechanization of maize production based on life cycle assessment: a case study in Jilin Province, China. Sustainability 7:15772-15784. https://doi.org/10.3390/su71115772

Wang Z, Wang M, Chen F (2015b) Carbon footprint analysis of crop production in North China Plain. Sci Agric Sin 48:83-92(In Chinese). https://doi.org/10.3864/j.issn.0578-1752.2015.01.09

Wang Z, Zhang H, Lu X, Wang M, Chu Q, Wen X, Chen F (2016) Lowering carbon footprint of winter wheat by improving management practices in North China Plain. J Clean Prod 112:149-157. https://doi.org/10.1016/j.jclepro.2015.06.084

Wang Z, Wang G, Han Y, Feng L, Fan Z, Lei Y, Yang B, Li X, Xiong S, Xing F, Xin M, du W, Li C, Li Y (2020) Improving cropping systems reduces the carbon footprints of wheat-cotton production under different soil fertility levels. Arch Agron Soil Sci 67:1-16. https://doi.org/10.1080/03650340.2020.1720912

West TO, Marland G (2002) A synthesis of carbon sequestration, carbon emissions, and net carbon flux in agriculture: comparing tillage practices in the United States. Agric Ecosyst Environ 91:217-232

West PC, Gerber JS, Engstrom PM, Mueller ND, Brauman KA, Carlson KM, Cassidy ES, Johnston M, MacDonald GK, Ray DK, Siebert S (2014) Leverage points for improving global food security and the environment. Science 345:325-328. https://doi.org/10.1126/ science. 1246067

Xue J-F, Yuan YQ, Zhang HL, Ren AX, Lin W, Sun M, Gao ZQ, Sun DS (2018) Carbon footprint of dryland winter wheat under film mulching during summer-fallow season and sowing method on the Loess Plateau. Ecol Indic 95:12-20. https://doi.org/10.1016/j. ecolind.2018.07.024 
Yadav GS, Lal R, Meena RS, Datta M, Babu S, Das A, Layek J, Saha P (2017) Energy budgeting for designing sustainable and environmentally clean/safer cropping systems for rainfed rice fallow lands in India. 158:29-37. https://doi.org/10.1016/j.jclepro.2017.04.170

Yadav GS, Das A, Lal R, Babu S, Meena RS, Saha P, Singh R, Datta M (2018) Energy budget and carbon footprint in a no-till and mulch based rice-mustard cropping system. J Clean Prod 191:144-157. https://doi.org/10.1016/j.jclepro.2018.04.173

Yang X, Gao W, Zhang M, Chen Y, Sui P (2014) Reducing agricultural carbon footprint through diversified crop rotation systems in the North China Plain. J Clean Prod 76:131-139. https://doi.org/10. 1016/j.jclepro.2014.03.063

Zhang H, Changrong Y, Yanqing Z, Jianbo W, Wenqing H, Baoqing C, Enke L (2015) Effect of no tillage on carbon sequestration and carbon balance in farming ecosystem in dryland area of northern China. Trans Chin Soc Agric Eng 31:240-247 (In Chinese)

Zhang X et al (2016) Tillage effects on carbon footprint and ecosystem services of climate regulation in a winter wheat-summer maize cropping system of the North China Plain. Ecol Indic 67:821-829. https://doi.org/10.1016/j.ecolind.2016.03.046

Zhu J (2015) Studies on $\mathrm{CO}_{2}$ emission and Carbon footprint of farmland in Song-nen Plain. Master Degree, Northeast Agricultural University (In Chinese)

Publisher's note Springer Nature remains neutral with regard to jurisdictional claims in published maps and institutional affiliations. 